Utah State University

DigitalCommons@USU

7-23-2018

\title{
Co-Dependency Between a Specialist Andrena Bee and Its Death Camas Host, Toxicoscordion paniculatum
}

James H. Cane

Utah State University

Follow this and additional works at: https://digitalcommons.usu.edu/piru_pubs

Part of the Entomology Commons

\section{Recommended Citation}

Cane, James H., "Co-Dependency Between a Specialist Andrena Bee and Its Death Camas Host, Toxicoscordion paniculatum" (2018). All PIRU Publications. Paper 798.

https://digitalcommons.usu.edu/piru_pubs/798

This Article is brought to you for free and open access by the Pollinating Insects Research Unit at DigitalCommons@USU. It has been accepted for inclusion in All PIRU Publications by an authorized administrator of DigitalCommons@USU. For more information, please contact digitalcommons@usu.edu.

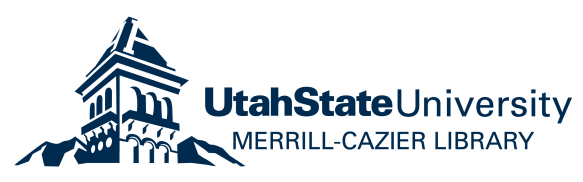




\title{
Co-dependency between a specialist Andrena bee and its death camas host, Toxicoscordion paniculatum
}

\author{
James H. Cane ${ }^{1}$ (D) \\ Received: 11 December 2017 / Accepted: 10 July 2018 \\ (c) This is a U.S. Government work and not under copyright protection in the US; foreign copyright protection may apply 2018
}

\begin{abstract}
Among associations of plants and their pollinating bees, mutually specialized pairings are rare. Typically, either pollen specialist (oligolectic) bees are joined by polylectic bees in a flowering species' pollinator guild, or specialized flowers are pollinated by one or more polylectic bees. The bee Andrena astragali is a narrow oligolege, collecting pollen solely from two nearly identical species of death camas (Toxicoscordion, formerly Zigadenus). Neurotoxic alkaloids of these plants are implicated in sheep and honey bee poisoning. In this study, T. paniculatum, T. venenosum and co-flowering forbs were sampled for bees at 15 sites along a 900-km-long east-west transect across the northern Great Basin plus an altitudinal gradient in northern Utah's Bear River Range. Only A. astragali bees were regularly seen visiting flowering panicles of these Toxicoscordion. In turn, this bee was never among the 170 bee species caught at 17 species of other prevalent co-occurring wildflowers in the same five state region (38,000 plants surveyed). Our field pollination experiments show that T. paniculatum is primarily an outcrosser dependent on pollinator visitation for most capsule and seed set. Thus, both A. astragali and two sister species of Toxicoscordion are narrowly specialized and co-dependent on each other for reproduction, illustrating a rare case of obligate mutual specialization in bee-plant interactions.
\end{abstract}

Keywords Apiformes $\cdot$ Breeding biology $\cdot$ Monolecty $\cdot$ Pollination $\cdot$ Oligolecty $\cdot$ Melanthiaceae $\cdot$ Zigadenus

\section{Introduction}

Most plant-pollinator interactions include partners that are taxonomic generalists, although many also involve specialists. Rarely are both the floral host and its pollinators mutually specialized. Some brood-site mutualisms exemplify the latter, such as Neotropical figs and their fig wasps, or yuccas and their yucca moths, but these insects actively pollinate their hosts (reviewed in Proctor et al. 1996). For bees and the plants that they passively pollinate while foraging, specialization seems generally asymmetrical (Vazquez and Aizen 2004), although evidence in support of this assertion was

Handling Editor: Kristine Nemec.

Electronic supplementary material The online version of this article (https://doi.org/10.1007/s11829-018-9626-9) contains supplementary material, which is available to authorized users.

James H. Cane

jim.cane2@gmail.com

1 USDA-ARS Pollinating Insect Research Unit (PIRU), Utah State University, Logan, UT 84322-5310, USA only mustered later by Minckley and Roulston (2006). On the one hand, diverse flowers with complex morphologies are typically pollinated by only a few generalist (polylectic) bees, such as the bumble bees (Bombus) that pollinate the asymmetrical flowers of Pedicularis groenlandica (Macior 1968). Conversely, species of oligolectic bees typically join generalists in more species-rich floral guilds (e.g. sunflowers, blueberries and willows) (reviewed in Wcislo and Cane 1996; Minckley and Roulston 2006), although the specialists are sometimes the superior pollinators (e.g. Larsson 2005).

Only a few examples represent mutually specialized bee-flower interactions, wherein a few oligolectic species are the flower's only visitors. These cases include Macropis bees foraging only at Lysimachia in the Holarctic (Vogel 1976); Brazilian Ancyloscelis gigas bees at Eichhornia azurea (Alves dos Santos and Wittmann 2000); Brazilian Ceblurgus longipalpis bees at Cordia (Milet-Pinheiro and Schlindwein 2010); several Euryglossa (Euhesma) bee species at Australian Verticordia (Houston et al. 1993), and in South Africa; Rediviva bee species at Diascia (Vogel and Michener 1985) or certain orchids (Pauw 2006). Half of these examples involve bees specialized to collect (Neff 
and Simpson 1981) and metabolize floral oils, although some oil-collecting bees are more taxonomically versatile (Schlindwein 1998). These narrow oligoleges are expected to be effective pollinators of their singular hosts, but evidence is sparse (Milet-Pinheiro and Schlindwein 2010).

A tantalizing additional example involves two intergrading species of death camas, Toxicoscordion paniculatum (Nuttall) Rydberg and T. venenosum (S. Watson) Rydberg (Zomlefer and Judd 2002). These are visited by a non-social bee species with the unfortunate epithet of Andrena (Euandrena) astragali Viereck and Cockerell (Tepedino 2003). Pollen loads taken from female $A$. astragali in the PIRU museum collection invariably consisted of Toxicoscordion pollen but never included Astragalus pollen; that host record is only known from Cockerell's single holotype specimen (Tepedino 2003). This bee's apparent pollen specificity is consistent with it being an oligolege of Toxicoscordion, although it might instead merely reflect strong floral constancy for Toxicoscordion, the plant at which all the females had been collected. For the plant's part, its dependence on pollinators cannot be concluded, as the breeding biology of $T$. paniculatum is poorly known. Its pollen-ovule ratios suggest substantial outcrossing (Tepedino 1981), but most of the pollination trials in that study were lost to livestock trampling. Frost damaged Emms' (1993) experimental panicles, leaving only 10-15 hand-pollinated flowers to evaluate. Hence, the pollination needs of $T$. paniculatum remain unknown, and so its need for pollinators.

The three objectives of this research were (1) to experimentally characterize the breeding biology of $T$. paniculatum (and so it's need for pollinators); (2) to assess the strict dependence of the bee A. astragali on T. paniculatum and $T$. venenosum, to the exclusion of other abundant co-flowering species used by other bee species in the same Intermountain wildflower communities; and (3) to document the geographical extent of their specialized relationship in the U.S. Intermountain Region using field surveys at bloom.

\section{Materials and methods}

\section{Systematics and natural history}

The taxonomic history of Toxicoscordion has been complex, both in tribal and familial affiliations (summarized in Zomlefer et al. 2001) as well as in generic and species circumscription. The generic assignment of North American Toxicoscordion has alternated with Zigadenus (Zomlefer and Judd 2002), but has reverted again to Toxicoscordion (McNeal and Zomlefer 2012). The several subtle floral characters used to distinguish T. paniculatum and T. venenosum are indistinct and overlapping, raising doubt about their specific status. For this reason, bee visitations to the two species are combined herein. Both species are herbaceous, bulbforming perennial geophytes. By May or June, depending on elevation, both species send up a single columnar panicle crowded with tiny, white, mostly hermaphroditic flowers with conspicuous tepal glands (Emms 1993; McNeal and Zomlefer 2012).

\section{Breeding biology}

Wild populations of $T$. paniculatum growing up Logan Canyon (Cache Co, Utah, USA) were used for experimental manual pollinations. During May and June, budded panicles were enclosed in fine mesh bags and each assigned a pollination treatment. Two manual pollination treatmentsgeitonogamy (transfer of self pollen) and xenogamy (outcrossing) - were applied thrice weekly to all open flowers of tagged panicles. By repeatedly hand-pollinating flowers on the same panicles over multiple days, we should have accommodated their protandrous tendencies (Emms 1993). Geitonogamous pollination involved manually rubbing recipient virgin stigmas with anthers of a flower clipped low on the same panicle. Donor flowers for xenogamy were taken from other plants in the local population. Optical visors were necessary to magnify all manipulations. Control panicles limited to autogamy remained bagged during bloom, while openly pollinated panicles were tagged but not bagged. Flowers were too small to emasculate in the field, so we cannot rule out the possibility of some geitonogamy resulting from stigmas inadvertently contacting pollen rubbed on the bagging fabric. Once seeds were nearing maturity, but before capsules had fully opened, each panicle's capsules were counted, harvested and returned to the laboratory to count their complements of plump brown seeds.

Treatments were compared for proportions of panicles producing no capsules using logistic regression. This first analysis was necessary because some treatments, especially autogamy, seldom yielded capsules. The excess of zero values (no capsules) resulted in hopelessly non-normal data that precluded an ANOVA. Convergence criteria were met for the logistic regression, however, and the proportional odds assumption accepted. The Wald test was the appropriate overall statistical test in this logistic analyses, given the sample sizes.

Reproductive responses of plants to the three manipulative treatments (autogamy, geitonogamy, xenogamy) and freely visited were then compared for all panicles that produced at least one capsule. The three measured response variables were (1) capsules per panicle; (2) total seeds per panicle; and (3) average number of seeds formed per capsule on a panicle. Square root transformation for seed counts corrected data skew. Normality of transformed data was checked by the Kolmogorov-Smirnov test (acceptable $P$ values $>0.005$ ). Homogeneity of variances was checked by Levene's test 
(acceptable $P$ values $>0.005$ ). Because treatment was fixed but panicle (plant) was random, a mixed model ANOVA was used (Proc MIXED) (Littell et al. 1996). Following a significant overall ANOVA, treatments were compared using an a posteriori multiple range test (least square difference), and one a priori contrast was made between autogamy + geitonogamy versus outcrossing + freely visited.

Means are reported with their associated standard errors; degrees of freedom are given in subscript brackets for test statistics.

\section{Pollinator faunas}

Bees were surveyed at flowers of Toxicoscordion at 15 sites sampled over 16 years along a latitudinal transect $900 \mathrm{~km}$ long from Oregon eastward through Idaho, Nevada and Utah to Wyoming (Fig. 1), all in sagebrush-steppe and juniper woodlands. Additional montane surveys in northern Utah's Bear River Range recorded A. astragali visiting Toxicoscordion and other co-flowering species. In addition, bee guilds at wildflowers that bloomed concurrently with local Toxicoscordion were systematically sampled at 28 sites across the same five-state region. Representative individuals are vouchered in the PIRU collection, whose database of 1.8 million specimen label records was queried for relevant bee-host associations.

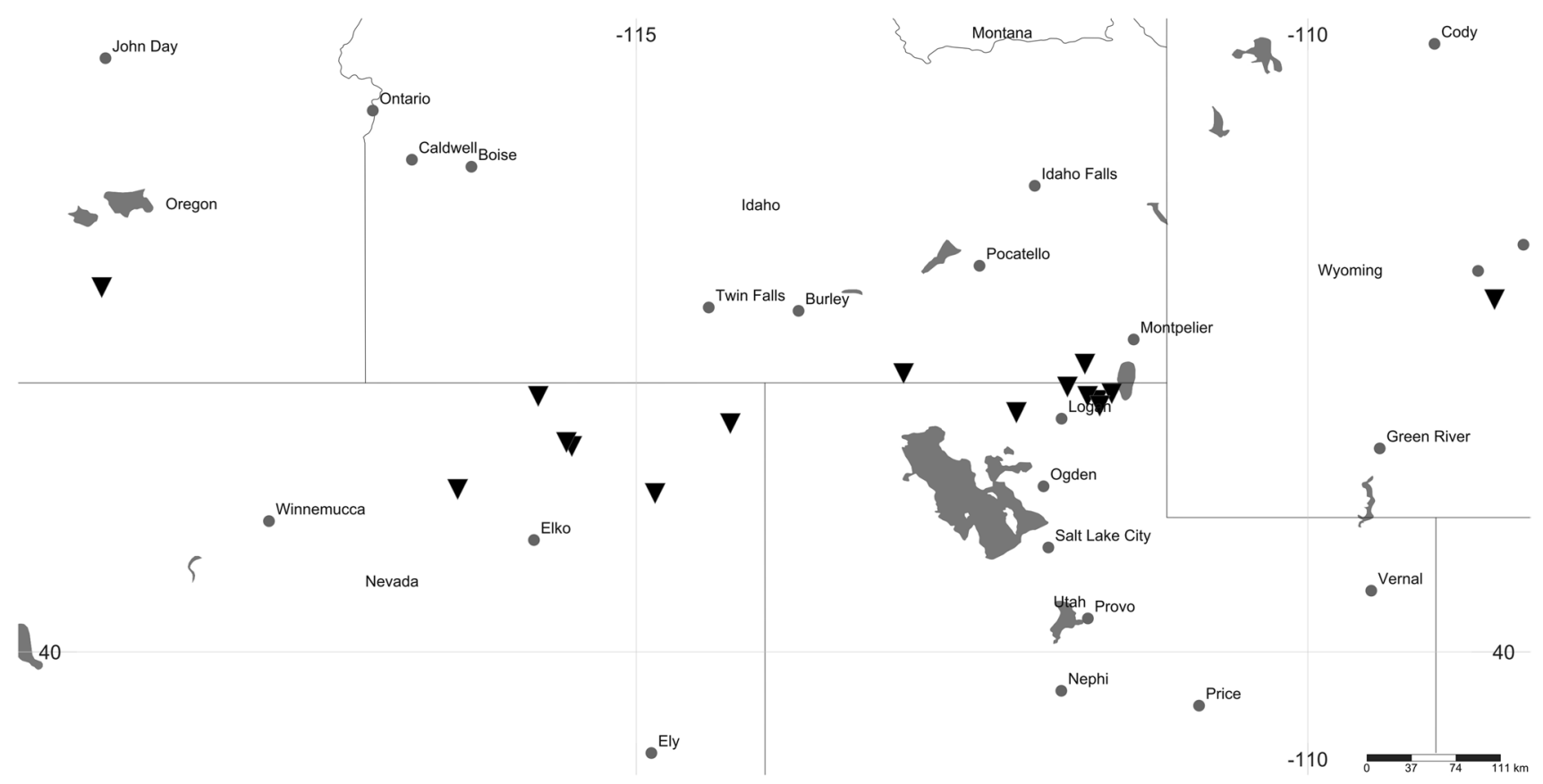

\section{Results and discussion}

\section{Breeding biology}

The probabilities of capsule formation varied with pollination treatment $(G=17.1, P \leq 0.0007)$. Of 104 panicles used, 36 set no capsules (Fig. 2). Outcrossing was fivefold more likely to yield panicles with some capsules than were either autogamy $(P \leq 0.024)$ or geitonogamy $(P \leq 0.0005)$

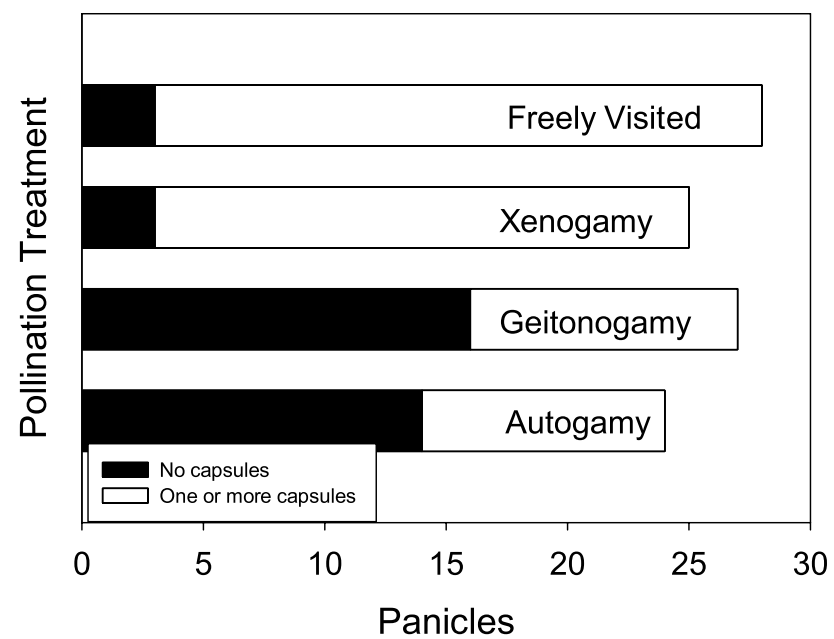

Fig. 2 Proportions of T. paniculatum plants whose flowering panicle yielded at least one capsule in response to pollination treatment

Fig. 1 Map of the northern U.S. Intermountain West showing sites where flowering populations of T. paniculatum or T. venenosum were surveyed for bees (black inverted triangles) 
(Table 1). Outcrossing was equivalent to open visitation in almost always generating one or more seeded capsules per panicle $(P=0.13)$ (Table 1 ; Fig. 3a).

Seed production per each of the 68 panicles with at least one capsule also varied significantly among pollination treatment groups $\left(F_{[3,64]}=3.3, P<0.026\right)$ (Table 1$)$. For 105 capsules taken from untreated plants, seed content averaged $8.2 \pm 0.5$ seeds (range 1-27). Yields of seed of experimental plants were similar between autogamy and geitonogamy $(P>0.4)$ and between outcrossed and openly visited panicles $(P>0.7)$ (Table 1$)$. The combination of xenogamy and openly visited panicles set more seeds per panicle than autogamy and geitonogamy combined $(F=9.3, P<0.003)$ (Table 1). Among the 51 autogamy and geitonogamy panicles, 3/4 of their total seed production came from just four of their most productive plants (Fig. 3b). In contrast, the four most productive panicles that had been outcrossed or freely visited contributed 55 and $40 \%$ of total seed production to those respective treatments. Thus, proportionately

Table 1 Capsule and seed production resulting from pollination treatments applied to panicles of $T$. paniculatum

\begin{tabular}{|c|c|c|c|c|c|}
\hline \multirow[t]{2}{*}{ Treatment } & \multicolumn{3}{|l|}{ Panicles } & \multirow{2}{*}{$\begin{array}{l}\text { Sum of } \\
\text { capsules }\end{array}$} & \multirow{2}{*}{$\begin{array}{l}\text { Sum of } \\
\text { seeds }^{1}\end{array}$} \\
\hline & $\begin{array}{l}\text { Number } \\
\text { treated }\end{array}$ & $\begin{array}{l}\text { Lacking } \\
\text { capsules }\end{array}$ & $\begin{array}{l}\text { Pct. lacking } \\
\text { capsules } \\
(\%)^{1}\end{array}$ & & \\
\hline Autogamy & 24 & 14 & $58^{\mathrm{A}}$ & 72 & $367^{\mathrm{a}}$ \\
\hline $\begin{array}{l}\text { Geitonog- } \\
\text { amy }\end{array}$ & 27 & 16 & $59^{\mathrm{A}}$ & 115 & $584^{\mathrm{a}}$ \\
\hline Outcross & 25 & 3 & $12^{\mathrm{B}}$ & 274 & $2163^{b}$ \\
\hline $\begin{array}{l}\text { Freely } \\
\text { visited }\end{array}$ & 28 & 3 & $11^{\mathrm{B}}$ & 371 & $2604^{b}$ \\
\hline
\end{tabular}

${ }^{1}$ Treatments with different superscript letters differed significantly from one another more outcrossed or freely visited plants contributed to sexual reproduction in their populations (Fig. 3a, b). For every seed set by autogamy or geitonogamy, 3.5 to sixfold more seeds resulted at manual outcrossed or openly visited panicles. Sexual reproduction by $T$. paniculatum mostly depends on pollinator visitation because the species is largely self-incompatible.

\section{Pollinator fauna}

With rare exception, the sole bee found visiting flowers of Toxicoscordion was A. astragali, both occasional males and many pollen-collecting females of this solitary, groundnesting bee. Their association extended over a wide range of both latitude (Fig. 1) and elevation (1430-2330 m), from basin sagebrush-steppe to montane meadows during the months of May and June. One additional bee species, Andrena (Trachandrena) amphibola (Viereck), was infrequently caught at $T$. paniculatum. One relatively young (no wing wear) female was taken from death camas at each of three sites along the ID-NV border in June 2017. This bee species generally flies in midsummer (LaBerge 1973) after T. paniculatum bloom has past. In the PIRU collections, $85 \%$ of the 149 female specimens of $A$. amphibola lack floral host labels. However, of the 23 females with floral labels, only six were caught visiting Toxicoscordion (as Zigadenus). The remaining 17 specimens were taken at flowers of 10 genera representing eight eudicot families. In contrast, $91 \%$ of the 53 female specimens of $A$. astragali with floral host labels were taken at Toxicoscordion. Excepting a single bumblebee seen briefly landing on several death camas panicles before departing, no other bee but $A$. astragali was seen visiting flowers of Toxicoscordion in 15 populations in five states (Fig. 1), although diverse and abundant spring bee communities were active at many of these locations. In Kansas,

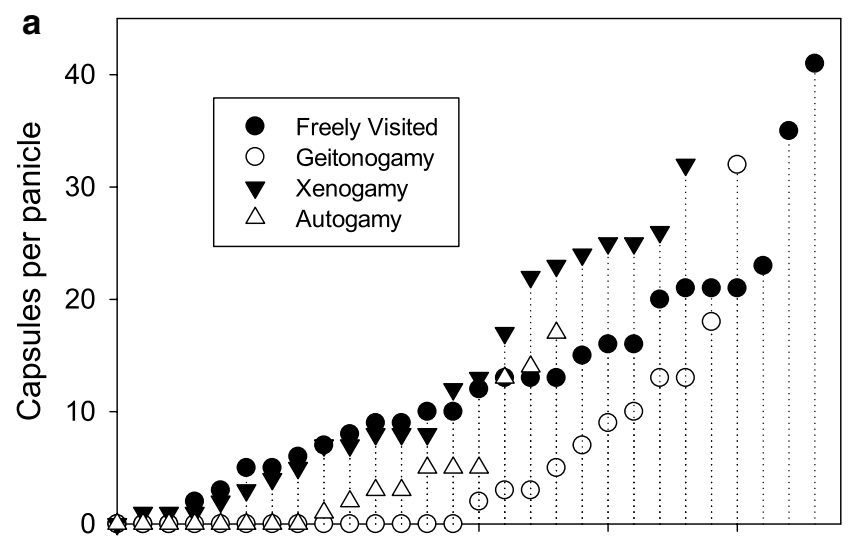

Panicle (in rank order)

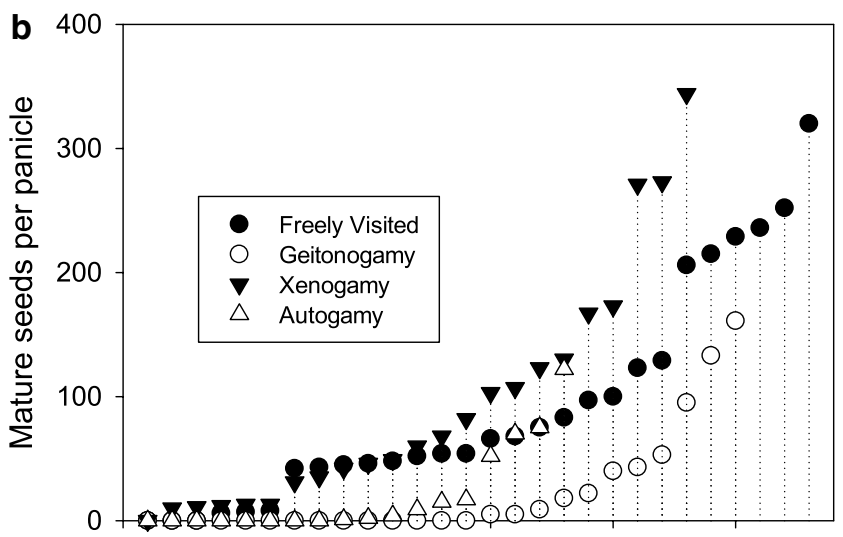

Panicle (in rank order)

Fig. 3 Reproductive responses of panicles receiving one of four pollination treatments: a capsules per panicle and $\mathbf{b}$ mature seeds per panicle 
flowers of another death camas (T. nuttallii) attracted numerous Dialictus sweat bees (Tepedino et al. 1989). At some but not all sites, flowers of T. paniculatum were also visited by the syrphid fly Eristalis hirta Loew, as Tepedino (1981) reported earlier. These flies were seen daubing the anthers with their proboscises; three dissected individuals had yellow pollen in their guts. Unfortunately, I neglected to consistently record their presence when surveying Toxicoscordion for bees.

Throughout the same 5-state region (Fig. 1), A. astragali was absent from systematic bee surveys at flowers of 17 species of prevalent, co-flowering floral hosts in these same habitats. The sole exception was one male A. astragali caught at Lomatium dissectum (Apiaceae). Bees visiting these dominant wildflower species were quantitatively sampled over 15 years by Cane and Love (2016). In all, 38,000 flowering plants were inspected for floral visitors, yielding $>3800$ individual bees representing $>170$ native bee species; none were $A$. astragali. For 28 basin sagebrushsteppe sites with flowering Toxicoscordion, an average of 12 other wildflower species were flowering concurrently, most commonly 1-2 species each of Astragalus, Balsamorhiza, Delphinium, Eriogonum, Lomatium, Lupinus and Phlox, representing six eudicot families. No species of Liliaceae sensu lato or Melanthiaceae were flowering at the time. In four montane plant communities of the Bear River Range in Northern. Utah, A. astragali was regularly seen visiting flowers of T. paniculatum but never any of the other 17-39 blooming wildflower species, which did include several monocots (Allium, Brodiaea, Smilacina and Triteleia). Not all Toxicoscordion attract bees; during several hours of observing large alpine patches of blooming T. elegans over multiple years in the Bear River Range, no bee was ever seen visiting its flowers. These surveys document both that A. astragali is consistently the sole bee to regularly forage at these two sister species of Toxicoscordion, and that it eschews the many other co-flowering species used by diverse other wild bees in these same habitats, thus fulfilling a key criterion for claims of mutual specialization (Minckley and Roulston 2006).

In the PIRU collection database, 816 females of the 16 other species of Euandrena bees (the subgenus of A. astragali) have floral hosts labels, but only 3\% (27) were caught at any other monocot flower, and none at Toxicoscordion or any Melanthiaceae. Several species appear to be oligoleges, but for other plant families (e.g. Asteraceae for A. lawrenci). Conversely, no other bee in the collection database had a floral label from any other Melanthiaceae found in North America (e.g. Trillium, Veratrum, Xerophyllum). Thus, there are no phylogenetic antecedents for the close association between A. astragali and Toxicoscordion, in contrast with findings of sister species of some other oligolectic genera of bees sometimes specializing on the same or related floral host genera (e.g. Sipes and Tepedino 2005).

This study bolsters the assertion that $A$. astragali bees and the species of Toxicoscordion that they visit for pollen and nectar are indeed mutually reliant upon each other for reproduction. Tepedino (2003) was convinced of this bee's narrow oligolecty after finding that Toxicoscordion pollen composed an average of $83 \pm 11 \%$ of the pollen in large loads borne by 49 female A. astragali specimens housed in the PIRU collection. Taken alone, that data could also merely indicate floral constancy, inasmuch as the bees were collected at Toxicoscordion. Floral survey data presented here show that the bee was only ever seen visiting flowers of Toxicoscordion, to the exclusion of other prevalent co-flowering plants, across a wide geographic region. Because all evidence indicates that Toxicoscordion species are the sole pollen host of $A$. astragali, the bee's reproductive dependence on death camas is apparent, although the most convincing proof of narrow oligolecty would come from larval pollen provisions taken across a series of sites, should nests ever be found.

The dependence of $T$. paniculatum on pollinators is shown by experiments with its breeding biology. Most capsules and seeds result from transfer of pollen between plants, as mediated by floral visitors. Wide-ranging field surveys show that $A$. astragali is the sole bee species visiting its flowers. Occasionally, the syrphid fly $E$. hirtus also was seen visiting death camas flowers as evidenced in earlier studies (Tepedino 1981; Emms 1993) and this study. The fly's effectiveness as a second candidate pollinator of Toxicoscordion needs evaluation (as is generally the case for many flowervisiting syrphid flies). Documenting single-visit pollination efficacies of $A$. astragali and this fly would be logistically daunting, but perhaps single-visit pollen deposition could be quantified despite its tiny crowded flowers. Even including the fly, it is clear that T. paniculatum is pollinated by at most two species of floral visitors despite its readily accessible floral rewards and the hundreds of other bee species active when and where it blooms.

Pollen and nectar rewards produced by $T$. paniculatum (and $T$. venenosum) go largely uncontested, likely because they are broadly toxic to bees. Vegetative tissues of the plants contain the neurotoxic steroidal alkaloid zygacine in sufficient quantities to kill sheep (Welch et al. 2013). Zygacine targets neural sodium channels, as do the pyrethroid insecticides which are also broadly toxic to bees but tolerated by some flies (Soderlund and Knipple 2003). Springtime kills of honey bees have been associated with death camas (Vansell and Watkins 1933). When T. venenosum pollen was blended with sugar syrup and fed to 100 caged honey bees, they all died within $48 \mathrm{~h}$ (Hitchcock 1959). Inasmuch as worker honey bees will also die of starvation in that amount of time, whether the toxin killed them or dissuaded them from feeding remains an open and relevant question 
for explaining the absence of all bee species but $A$. astragali at flowers of these Toxicoscordion species. Demonstrating apparent tolerance of dietary zygacine by adult Eristalis flies and adult and larval $A$. astragali bees will require quantifying the presence, if any, of zygacine in Toxicoscordion pollen and nectar, followed by bioassays to evaluate feeding deterrence and/or mortality resulting from biologically relevant ingested doses of this alkaloid.

The mechanism that enforces this tight mutual specialization of narrowly oligolectic $A$. astragali bees and their few Toxicoscordion floral hosts is clearly different from those that define the few other cases of such mutual specialization (e.g. floral oils, heterostyly).

Acknowledgements Carole Scofield and others assisted with the exacting field pollinations and seed processing. Harold Ikerd at PIRU searched the museum specimen database. Byron Love was integral to bee collections at wildflowers. Dr. Vincent Tepedino provided a detailed, constructive review.

\section{References}

Alves dos Santos I, Wittmann D (2000) Legitimate pollination of the tristylous flowers of Eichhornia azurea (Pontederiaceae) by Ancyloscelis gigas bees (Anthophoridae, Apoidea). Plant Syst Evol 223:127-137

Cane JH, Love B (2016) Floral guilds of bees in sagebrush steppe: comparing bee usage of wildflowers available for postfire restoration. Nat Areas J 36:377-391

Emms SK (1993) Andromonoecy in Zigadenus paniculatus (Liliaceae)—spatial and temporal patterns of sex allocation. Am J Bot 80:914-923

Hitchcock JD (1959) Poisoning of honey bees by death camas blossoms. Am Bee J 99:418-419

Houston TF, Lamont BB, Radford S, Errington SG (1993) Apparent mutualism between Verticordia nitens and V. aurea (Myrtaceae) and their oil-ingesting bee pollinators (Hymenoptera, Colletidae). Aust J Bot 41:369-380

LaBerge WE (1973) A revision of the bees of the genus Andrena of the Western Hemisphere. part VI. subgenus Trachandrena. Trans Am Entomol Soc 99:235-371

Larsson M (2005) Higher pollinator effectiveness by specialist than generalist flower-visitors of unspecialized Knautia arvensis (Dipsacaceae). Oecol 146:394-403

Littell RC, Milliken GA, Stroup WW, Wolfinger RD (1996) SAS system for mixed models. SAS Inst. Inc., Cary

Macior LW (1968) Pollination adaptation in Pedicularis groenlandica. Am J Bot 55:927-932

McNeal DW, Zomlefer WB (2012) Toxicoscordion. In: Baldwin BG, Goldman DH, Keil DJ, Patterson R, Rosatti TJ, Wilken DH (eds) The Jepson manual. Vascular plants of California. University of California Press, Berkeley, pp 1395-1396
Milet-Pinheiro P, Schlindwein C (2010) Mutual reproductive dependence of distylic Cordia leucocephala (Cordiaceae) and oligolectic Ceblurgus longipalpis (Halictidae, Rophitinae) in the Caatinga. Ann Bot 106:17-27

Minckley RL, Roulston TH (2006) Incidental mutualisms and pollen specialization among bees. In: Waser NM, Ollerton J (eds) Plantpollinator interactions: from specialization to generalization. Chicago Press, Chicago, pp 69-98

Neff JL, Simpson BB (1981) Oil-collecting structures in the Anthophoridae (Hymenoptera): morphology, function, and use in systematics. J Kansas Entomol Soc 54:95-123

Pauw A (2006) Floral syndromes accurately predict pollination by a specialized oil-collecting bee (Rediviva peringueyi, Melittidae) in a guild of South African orchids (Coryciinae). Am J Bot 93:917-926

Proctor M, Yeo P, Lack A (1996) The natural history of pollination. Timber Press, Portland

Schlindwein C (1998) Frequent oligolecty characterizing a diverse beeplant community in a xerophytic bushland of subtropical Brazil. Stud Neotrop Fanua Environ 33:46-59

Sipes SD, Tepedino VJ (2005) Pollen-host specificity and evolutionary patterns of host switching in a clade of specialist bees (Apoidea: Diadasia). Biol J Linn Soc 86:487-505

Soderlund DM, Knipple DC (2003) The molecular biology of knockdown resistance to pyrethroid insecticides. Insect Biochem Mol Biol 33:563-577

Tepedino VJ (1981) Notes on the reproductive biology of Zigadenus paniculatus, a toxic range plant. Great Basin Nat 41:427-430

Tepedino VJ (2003) What's in a name? The confusing case of the death camas bee, Andrena astragali Viereck and Cockerell (Hymenoptera: Andrenidae). J Kansas Entomol Soc 76:194-197

Tepedino VJ, Knapp AK, Eickwort GC, Ferguson DC (1989) Death camas (Zigadenus nuttallii) in Kansas: pollen collectors and a florivore. J Kansas Entomol Soc 62:411-412

Vansell GH, Watkins WG (1933) A plant poisonous to adult bees. J Econ Entomol 26:168-170

Vazquez DP, Aizen MA (2004) Asymmetric specialization: a pervasive feature of plant-pollinator interactions. Ecology 85:1251-1257

Vogel S (1976) Lysimachia: Ölblumen der Holarktis. Naturwissen 63:44-45

Vogel S, Michener CD (1985) Long bee legs and oil-producing floral spurs, and a new Rediviva (Hymenoptera: Melittidae, Scrophulariaceae). J Kansas Entomol Soc 58:359-364

Wcislo WT, Cane JH (1996) Floral resource utilization by solitary bees (Hymenoptera: Apoidea) and exploitation of their stored foods by natural enemies. Annu Rev Entomol 41:195-224

Welch KD, Green BT, Gardner DR, Stonecipher CA, Panter KE et al (2013) The effect of low larkspur (Delphinium spp.) co-administration on the acute toxicity of death camas (Zigadenus spp.) in sheep. Toxicon 76:50-58

Zomlefer WB, Judd WS (2002) Resurrection of segregates of the polyphyletic genus Zigadenus s.l. (Liliales: Melanthiaceae) and resulting new combinations. Novon 12:299-308

Zomlefer WB, Williams NH, Whitten WM, Judd WS (2001) Generic circumscription and relationships in the tribe Melanthieae (Liliales, Melanthiaceae), with emphasis on Zigadenus: evidence from ITS and L-TRN-F sequence data. Am J Bot 88:1657-1669 